\title{
Sustainable Investment in the Heritage Areas Khedivial Cairo as a case study
}

\author{
Prof. Dr. Mahmoud Mohamed Fathi Al-Alfy \\ Professor of Architecture, Architecture Department \\ Faculty of Engineering,Zagazig University
}

\author{
Ass. Prof. Ahmad Elshahat Elmenshawy \\ Associate Professor, Architecture Department \\ Faculty of Engineering, Zagazig University
}

\author{
Ass. Prof. Heidi A. Shalaby \\ Associate Professor, Architecture Department \\ Faculty of Engineering, Zagazig University \\ Eng. Hala Mehany Mahmoud Salem \\ Teaching Assistant Department of Architecture \\ The Higher Institute of Engineering in Bilbes
}

\begin{abstract}
Heritage is the civilization and cultural wealth throughout the ages, so that the urban heritage and buildings are the physical witness of that civilization. Despite the fact that heritage is the most important factor in the economic development of any society, it suffers from deterioration especially in Arab Countries. Raising the awareness of the importance of investment in urban heritage in general and of sustainable investment in particular has been increased recently. The aim of the investment in heritage areas is to revive economic activity by reviving the values of heritage and society. Investment is considered one of the most important factors in the field of urban conservation, as it intervenes to determine the priorities of preserving and selecting its policies to deal with heritage areas ${ }^{1}$.

This paper aims to putting the view of sustainable investment on the processes of urban conservation. To achieve this goal, descriptive method is used to know the concepts of investment and urban conservation. Then deductive method is used to suggest the mechanism of sustainable investment on the heritage areas. And for example the famous European heritage cities like Paris, the statistics indicates that roughly $80 \%$ of its visitors are attending the heritage areas. The main addition of the research is to suggest the sustainable investment as a part of the management of the heritage areas.
\end{abstract}

Keywords :- Investment -heritage areas -sustainable development-touristic employment-financing

\section{RESEARCH PROBLEM}

Many problems resulted from contradiction between urban conservation and investment, we find that resources are not distributed according to an economic methodology activates the role of investment and shortage of participation of investors, in addition to the urban conservation of heritage, necessity of encouraging investment in the processes of periodic maintenance of buildings providing new ways to support the projects of urban conservation. The sustainable investment is spent for urban conservation an investment revenue. To assure the participation of new stakeholders as private sector (banks, investors, tour guides) in the projects of urban conservation, this results in complete benefit from available resources and experiences.

\section{INTRODUCTION}

Study of investment in the heritage areas is one of the economic studies of the heritage areas. It advocates the social aspects by increasing the income of people and improving the urban environment of heritage areas, conservation of cultural aspects and heritage areas. This can be done by making plans through true scientific ways at all political, social and applied levels of urban conservation, and keeping it for the future generations, which is called the sustainable development. Thus, we handle how to make a successful investment plan, coordination between the responsible administrative authorities by achieving required finance (sustainable). Good administration relies upon the participation of sustainable investment and partnership of private sector. Sustainable investment is a requirement to assure some kinds of finance. And according to the globalization, the urban heritage which its owner cannot benefit from, the concerned country.Urban heritage is owned by all. It requires support to manage and keep by investors, banks, private sector, international organizations. As urban heritage is important, all seek to try all ways including investment and sustainable development of these areas ${ }^{2}$.

The role of investment to maintain the urban heritage lies in material participation in projects of construction and employment of heritage areas and preparation of plans and marketing programs. Also, making investors participate in tourism industry has a great importance as tourism cannot be provided by public sector only ${ }^{3}$. Investors alsohave an administrative sufficiency andcompetitive ability. Area of Khedivial Cairo is particularly handled as it has special value regarding location and archeological and urban content including different cultures. It represents the heart of the city of heritage aspect, and providing administrative strategy helps create economic chances and different view of the architectural and urban effect relies on directing urban development of the existing areas in the city and the new areas. Material disintegration of these areas does not deprive it of its cultural distinguishing, this makes reuse of it of lower cost and more revenue simultaneously. 


\section{RESEARCH TARGET}

Main target lies in clarifying the relation between the sustainable investment and processes of urban conservation of heritage areas. By achieving this target one can put a mechanism gathers all ways by which sustainable investment can be made in the projects of conservation of heritage areas through plurality of parties participating locally and worldly. In addition, in private sector, if there is no clear investment economic outlook for any work, this work cannot be made or completed according to the plan, by three secondary aims:

- First aim:employing sustainable investment in projects of urban conservation.

- Second aim:designating a mechanism for organizing different ways of sustainable investment.

- Third aim:achieving sustainability for investment as an assurance for sustainability of conservation processes.

\section{METHODOLOGY OF RESEARCH PAPER}

Study depended on using the descriptive method, then deductive method to achieve the target of research as follows:

Descriptive method (theoretical study)to know the mutual relation between the sustainable investment and the methodology of urban areas administration by clarifying the concept of sustainable development and investment, then study of the importance of sustainable investment in the projects of urban areas administration.

Deductive methodby recognizing the most important characteristics and deducing some main determinants of mechanisms which can be followed by all and can be applied to this part, Khedivial Cairo .

\section{THEORETICAL STUDY}

\subsection{Suggested definitions}

\subsubsection{Sustainable investment}

Some strategies which merge economic considerations with sustainability considerations which is a way to achieve long term revenues and lessening the hazards of investment and using energy ${ }^{4}$.

\subsubsection{Heritage areas}

It is the valuable areas to be maintained and keep its nature, which conforms to the urban harmony basics and standards. It is areas include buildings, squares, streetsin addition to types of use and activities there ${ }^{5}$. Thus, these areas must besocially, economically and urbanely maintained and supported to be activated in itself, there is no need for other interventions after finishing projects of urban conservation.

\subsubsection{Reemployment}

It is one of the policies of urban conservation, it aims at conservation of the heritage building, and assurance of future maintenance, and also improving the urban environment. Reuse of heritage building is one of the best economic ways,it is not expensive as establishing new building. It is an assurance to find an economic rule based on for maintaining the building. The new use of building must achieve non conformity with the artistic, heritage and historical values to achieve suitability of the visual nature of the building and the spatial, job and constructive suitability ${ }^{6}$.

\section{2 value of heritage areas ${ }^{7}$}

These areas ownsscarcity which provides big chances of direct economic profit, there are many and varioustargets and requirements to put administrative methodology for conservation of heritage areasincluding aesthetic and cultural values. But here we spot light on the economic value of these areas especially heritage areas which have no support to achieve the required conservation, so economic justifications has priority, it is represented as follows:

- Private sector investment attraction

Private sector investment of existing urban heritage buildings is one of the investment fields applied on worldly level, whether heritage buildings are partially and totally populated or unpopulated.

- A way to provide more job opportunities

Stability of population as a result of relation to their jobs which are allowedby investment projects of heritage areas leads to a lot of economic, social and cultural benefits resulted from rehabilitation projects, employment of many heritage villages,centers of historical cities, popular markets, spread historical citadels and palaces.

- A way for revitalization oftraditional occupations and crafts

In the invested heritage location small workshops and factories arise for manufacturing what conforms or similar to what is ancient and heritage, craftsmen tried to develop the manufacture of handmade products which are recently used and gives their families good profits, and there are job opportunities for the local society.

- Popular and societal participation

The local society urged investment in reconstruction of urban heritage, this is recently noticed in a lot of the developing villages, and completion of the project will grant the society job opportunities to operate it, whether it is a project of dwelling, heritage hotel, restaurant or café.

- One of the sustainable resources

Plurality of locations gives the investor opportunities to select the location as for level importance, it also grants an opportunity for various and continuous investment resources. One of the characteristics of urban heritage buildings that it represents resourcescan be invested instead of constructing new buildings to benefit the investor by providing the value of constructions, and thus this achieve more actual income of investment revenues which is represented in the amount which can be spent for constructing new buildings. And in the same time it reemployed the urban heritage which achieveother investment opportunities supporting the main investment. These opportunities are available for local societies and organizations which resulted from economic revenues sustainably. 
7.3 Importance of sustainable investment in heritage areas

Sustainable investmentassures the importance of benefits and revenue from heritage resources represented in the constructed environment and accompanying economic activities whether equally from the economic, social or environmental perspective. Governments work in the free economy system to provide circumstances and atmosphere encouraging investment as total of businessmen fortunes is considered an important part of country fortune. Investors occupy distinctive locations as they take their power source from the economic relations in the international market and from their distinction in their homes. And free economy declares that profit margin which motivates businessmen to make new investments while the previous systems criminalize this target and consider it making use of citizens $^{8}$. This is represented in these points:

- Support by necessary finance to complete the urban conservation projects.

- Making small projects to support the big project, and encouraging the partnership of small investors.

- Private sector partnership provides the governmental effort for big projects and giving help to the governmental spending.

- Government is unable to do all projects without any international support (technical-financial).

- Distribution of risks resulting from establishing projects betweenmore than one party of the partnership.

- Private sector partnership increases (investors from the people of the area) the social awareness of population.

\section{4 ways of sustainable investment}

Ways of sustainable investment is classified in the urban heritage locations for many ways to be turned into areas of investment attraction, and represent national income and encourage investors to invest in it.

7.4.1 Establishing a company for country owned heritage buildings investment

There are two different types, first type: this company participates or finances only in existing projects or under construction, its role is the financial aspect and to follow it. Second type: to study the market and owners conditions in the target areas, and to purchase and finance properties in these areas, then to benefit from monthly or yearly revenues for these properties. Company is financed through these following sources 9 :

- Government participates in investments proportionally according to service benefit or agreed facilities.

- Coalition of private sector investors.

- Commercial loans, investors obtain loans from specialized financial institutions by country support.
7.4.2 Sustainable tourism for investment in heritage areas

Term of sustainable heritage tourism appeared as a distinguished field in tourism by relating it to the cultural heritage andas a result of increasing concerns of tourism. The government made use of marketing of heritage areas in which touristic resources are available, it can be developed to attract visitors and tourists to these areas and satisfying their desires to recognize this heritage ${ }^{10}$.

Sustainable tourism has become a methodology upon which the world touristic institutions are based, applying its concept is considered costly from the financial side, it has material and intangible revenues, itgrants the touristic institutions profit and benefit. After tourism industry, local society and environment are considered three separate item, concept of sustainability which is related to tourism came to consider the relation between these items which has been found to affect and be affected by each other viathe process of touristic development and touristic sustainability as the case for sustainability of other industries.

\subsubsection{Approaches of investment employment}

Investment employment aims at conservation of these locations for the sustainability of its earnings, and making it ready to be suitable for establishing a lot of investment activities, especially when practicing it in the locations of urban heritage which grants an additional value to the basic value of these heritage or non-heritage products is one of the activities. So, the sustainable investment activities give investment chances in totality to the private sector, through which social, economic and cultural benefits can be made to be directly or indirectly granted to all individuals and institutions. The most important aspects are indicated as follows ${ }^{11}$ :

Employing by establishing service and commercial centers, its investment is considered one of the best available chances of the private sector especially costs of construction are relatively low as a result of preparation of arenas publically. The expected investment revenue will be relatively high because of permanent request. In addition, investment in establishing these centers is very suitable for individual investors and small investment institutions.

- Employment to practice the entertaining and cultural activities, some locations of urban heritage allows for the private sector opportunity to organize and develop arenas and passages between fiber of urban heritage against small charges in addition to getting some services.

- Employing in other various activities, locations of urban heritage have abilities qualify it to employ a lot of various activities and keeping buildings as it is in case and basic shape.

- Employing as locations for practicing folkarts,folk artsis distinguished with big popular approval, this requires sufficient areas during performance of artistic movements. Thus, these areas must be invested by developing, preparation and designing again. 
- Employing as a dwelling place,employing urban heritage buildings is one of the best ways for conservation from being destroyed, either always by its owners or investing it by private sector.

- Employing as national museums, urban heritage buildings is one of the best locations for museum exhibition either by the individuals who have the hobby of collecting rare monuments or by ministries or governmental authorities responsible for conservation and maintenance of folk heritage.

- Employing as restaurants in private sector, investors always prepare,restore and maintain old heritage buildings to be allocated as restaurants in which popular food is provided.

- Employing as places for practicing crafts,a lot of workers in manufacturing all kinds of heritage and traditional products are related with practicing their jobs in workshops and labs located sometimes at the historical locations of the urban heritage, this adds heritage senseto the value of their products along with the place taste.

\subsection{The financingauthorities of sustainable investment ${ }^{12}$}

Investment in locations of urban heritage can be divided into:

\section{- Governmental investment:}

The state participates in restoration and rebuilding some urban heritage buildings for the purpose of protection and using it as buildings by reemploying it and using it in the field of tourism.

- The shared investment between government and private sector:

Some heritage locations are owned by the state, it is agreed with some investors to invest against sharing profits according to agreed proportions and according to standards and item of agreement between them.

- Private sector investment of heritage locations:

Preparation of the investment environment and overcoming the investment drawbacks, and exerting efforts for incentives.In addition, conservation of heritage locations encourages sustainable investment in these locations.

7.6 Drawbacks of the investment approach of heritage areas

Sustainable investment faces some drawbacks which face stakeholders from many aspects which can be clarified as follows:

Laws and legislations:no sufficient laws are related to organizing establishing buildings in heritage areas for conservation of architectural heritage, no definite policies to deal with dwellings, traditional squares, surrounding areas or reestablishing demolished urban heritage buildings, led to no definite responsibilities of the state, relevant authorities and individuals regarding that many urban heritage in heritage areas is private property.

Weak administration of heritage locations:no plans forvisitors administration and providing necessary services which are needed in most of urban heritage locations. The weak administration of tourism and relation of tourism to development may affect the structure of heritage locations.

Financing:loss of many heritage resources because of disintegration resulted from neglecting the heritage location leads to the increase of cost of heritage maintenance and shortage of finance leads to more disintegration of this heritage.

Marketing: focus on cultural employment of some urban heritage buildings which are restored and used as museums and cultural centers, and not thinking about economic employment which achieves resources and independence of financial resources.

Coordination and partnership:no network and communication process with the international authorities concerned with conservation of heritage to make use of international experiences in this regard, and no coordination in roles of state sectors as government sector, private sector and civil society ${ }^{13}$.

We find that investmentprogramsare so much and investment has many shapes as the country directly invested in heritage areas for a limited period of time by achieving development and economic investment to find successful investment experiences considered by local people and investors.

\section{APPLIED STUDY (KHEDIVIAL CAIRO)}

\section{1 location}

Area of (Khedivial Cairo) is located at the center of Cairo, capital of Egypt. It is alocation rich with architectural and urban distinction rather than other historical squares in Cairo. It is bordered from the east with historical Cairo, and from the west the Nile, from the north Ramsis square, and from the south Garden city area ${ }^{14}$. It has a nature recognized by the visitor from the first hint as it enjoys richness and deepness of clear heritage evidence by deducing historical, urban, architectural and job values of the area. It is an important and vital area from the urban, economic and social perspective.

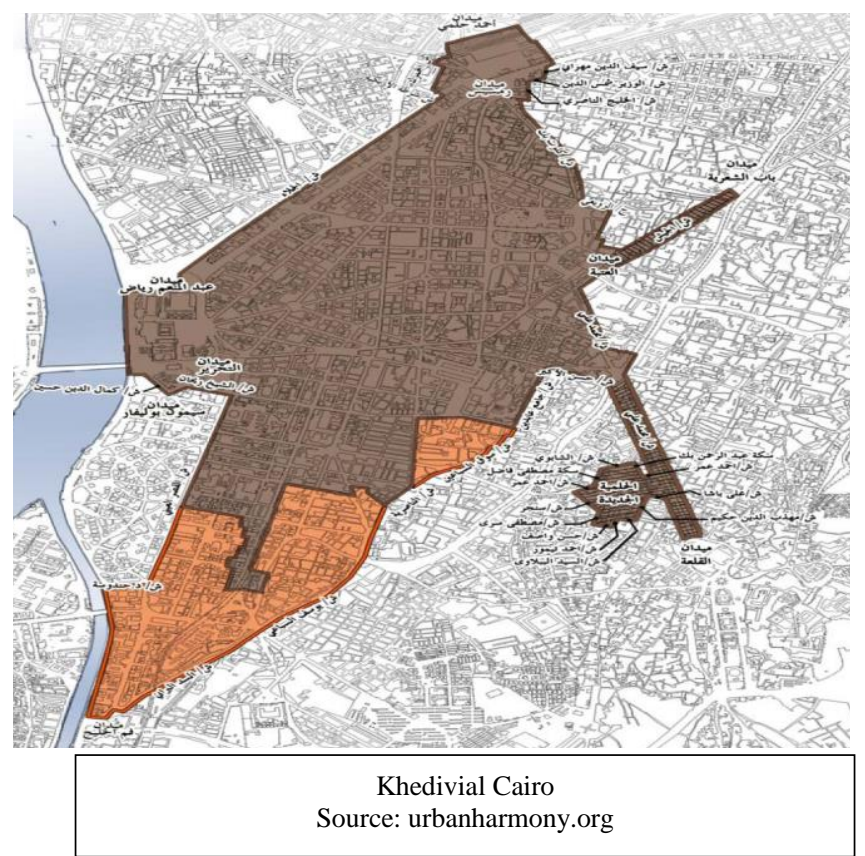




\subsection{Heritage value}

Khedivial Cairo is selected as it has urban tissue considered a turning point of urban in Egypt. Its streets are straight and has turns appeared in the shape of squares. Architecture in Egypt in nineteenth centuryhas turned to imitation, and movement from European style and to the modern style of renaissance age, then French, and to Italian and then to English.

\section{Most important merits are clarified as follows ${ }^{15}$ :}

- Distinctive location at the center of Cairo, and harmonious urban tissue between straightforward streets and wide squares.

- Harmonious nature by heights define and gather various classical architectural styles.

- Egyptian human heritage museum hasa lot of heritage buildings reach 300 buildings of an area of 700 feddans.

Job value is based on centralization of service, public, commercial, vocational, cultural, educational, professional and religious buildings, it increases job value within the great balance of urban heritage conserving the vital and pragmatic role. It is considered a strong economic central point has great investments for centralizing the abovementioned activities. Thus, the ability of suggesting the idea of relying upon the job value of the area by directing and pushing investment to manage the area heritage and to support the urban conservation processes in the $\operatorname{area}^{16}$.

Despite its presence as a buffer zone in historical Cairo, it has not been registered as a world heritage till now, in addition to its standards of world heritage and its containment of all basics of sustainable investment.

6.2 Ways of investment of finance authorities of Khedivial Cairo

The national committee for developing the heritage Cairo has constituted four peripheral committees including committee of investment and finance. It contains many finance experts to explore the ideal mechanisms to urge the local and international small and big entities, and to attract them for investment in the area. Sustainable investment faces many challenges facing stakeholders regarding level of finance, experiences and plans preparation. There are two approaches of finance ${ }^{17}$ :

\subsubsection{Governmental investment (self financing)}

Ideal usage of valuable abilities (material resources) in the areas as it is the center of Cairo, and the commercial center.Because of availability of many heritage resources represented in the buildings of historical value, it is easy to get necessary finance to complete the sustainable development projects by activating tourism of these heritage properties.

Constituting board of trustees of Alalfy and Saray AlAzbakiastreet and Orabi square, it contains head of AlAzbakia square and number of owners of properties and shops to set ideas and good suggestions to upgrade area and to activate it by participation of the executive authority of the square. This can be done by a regular meeting with head of square every two weeks, then a monthly meeting with governor to show any achievements or drawbacks to participate in solving it according to the conditions of organization for urban harmony. It is considered an application of successful sample for citizen participation in development process.

There are four chief determinants in Khedivial Cairo as one of the ways of sustainable investment ${ }^{18}$ :

- Material resources:it includes the touristic landmarks, facilities, transportation and infrastructure. Attraction places playa pivotal role in attracting tourism to façade. Thus, there must be an easy movement to the façade and good infrastructure, for example (electricity, sewage and communications) to support the enjoyable and safe travel in the area. There must be sufficient hotels and restaurants to meet the needs of tourists.

- Human resource:local people provide hospitality resources as hosts and providers of personal services, as the local cultures and life styles attracts tourists in many times. Society people must recognize tourism benefits.

- Available offers: all destinations havegroup of offers and programs can be purchased and used by tourists. All offers are collected by travel agencies and tour organizers. It is organized byareas to be visited or journey ways which are based on tour companies.

- Programs:events, festivals or activities are arranged or programmed for tourists, as these well marketed andwell designedfestivals and events attract tourists to destinationsto share this role with attraction factors. Programs of activities are previously arranged for tourists of special concerns. 


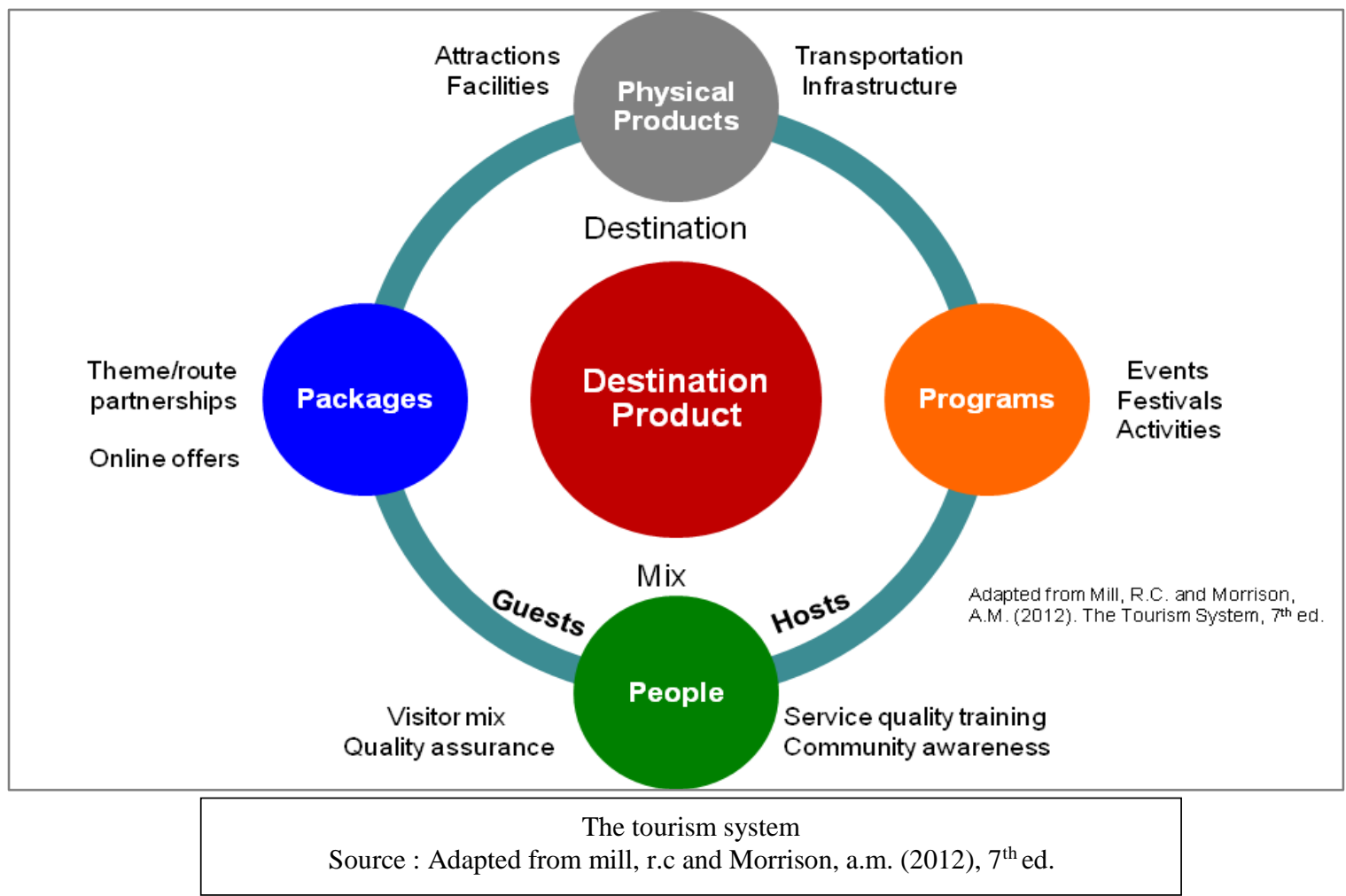

\subsection{2 shared investment between government and private sector (indirect financing) ${ }^{19}$}

In addition to self financingthere are some projects need indirect financing authorities represented in interfere of government to make executive procedures easy and completion of projects through providing public services, and societal participation and awareness programs by following the good harmony with area owners.

Al Ismaelia for real estate investment (SAE) is an Egyptian company established at 2008, to return the classical greatness of center of Cairo, west of the country, and conservation of urban heritage and experiencing it. The company is specialized in obtaining main real estate real estates in center of Cairo. Al Ismaelianow has a distinctive location of heritage in the center of the city. Its aim is to be a leading real estate investment company owns,manages, restores, rentshistorical areas to make a modern experience merge the historical heritage of downtown and modern culture.

View of Al Ismaeliais represented in returning continuous pride to center of Cairo as it provides new investment opportunities by providing unique chance in real estate sector in Egypt, and keeping confidence of current investors in the area. The company greatly focuses on revival of city center area by supporting and advocating the artistic and cultural view, and creating vital and positive destination with a wide group of events to attract people to living, working, marketing and communication.
For evaluating the economic, artistic and legal benefit to return and improve the passages, project of developing the western area is suggested. Thus, to determine and prove the nature of special and public interventions necessary to renew the network and to allow entering of new cultural and commercial usages complete the retail along the main streets, we find that this area focuses on Lavinoiz hotel in the intersection of Champlion street and Mahmoud Bassiouny, and Radio cinema in front of TalaatHarb. The central location of area near Egyptian museum, hotels overlook the Nile and availability of group of recreational places gives chance to renew Vienna hotel, Boutique hotel, and developing recreational and cultural activities in these real estates. We find that Radio cinema with two of distinguished rooms near hotels overlook the Nile create a unique chance to be turned into multimedia conference room, and connection between Radio cinema andLavinoiz is enough to setup a passage connect between TalaatHarb streets, Champlion and Mahmoud Bassionywhich can be arranged by commercial and cultural uses.

Main targets of this project:

- Be sure of nature of improvements and developments to be made on the public ways.

- To determine new complement uses to be developed by property owners.

- To determine the institutional arrangements necessary to assure cooperative intervention between governorate and property owners.

- To suggest the organizational mechanisms to assure the quality of improvements which will be inserted in the existing buildings and architectural urban characteristics of new buildings. 
Based on the results, the following will be done:

- Developing principles of improvement strategy of distributing passengers and inserting new usages.

- Determination of legal and institutional drawbacks against execution of strategy.

- Setting up clear complementaryroles for the private sector investors and governorate to achieve successful execution of a long term strategy of Khedivial Cairo.

- Accrediting policies to cure the drawbacks against the private investments as rentals subject to control in old buildings.
We find that societal participation is a positive factor for the Khedivial Cairo as it gives sense of collective responsibility and increase the ability to make correct decisions, and achieve the best use of available material resources, and achieve the targets by encouraging the target development works, and to support the feelings of belonging to the historical background which leads to urging the people of area to participate in the human and material financing for completing the sustainable development projects.
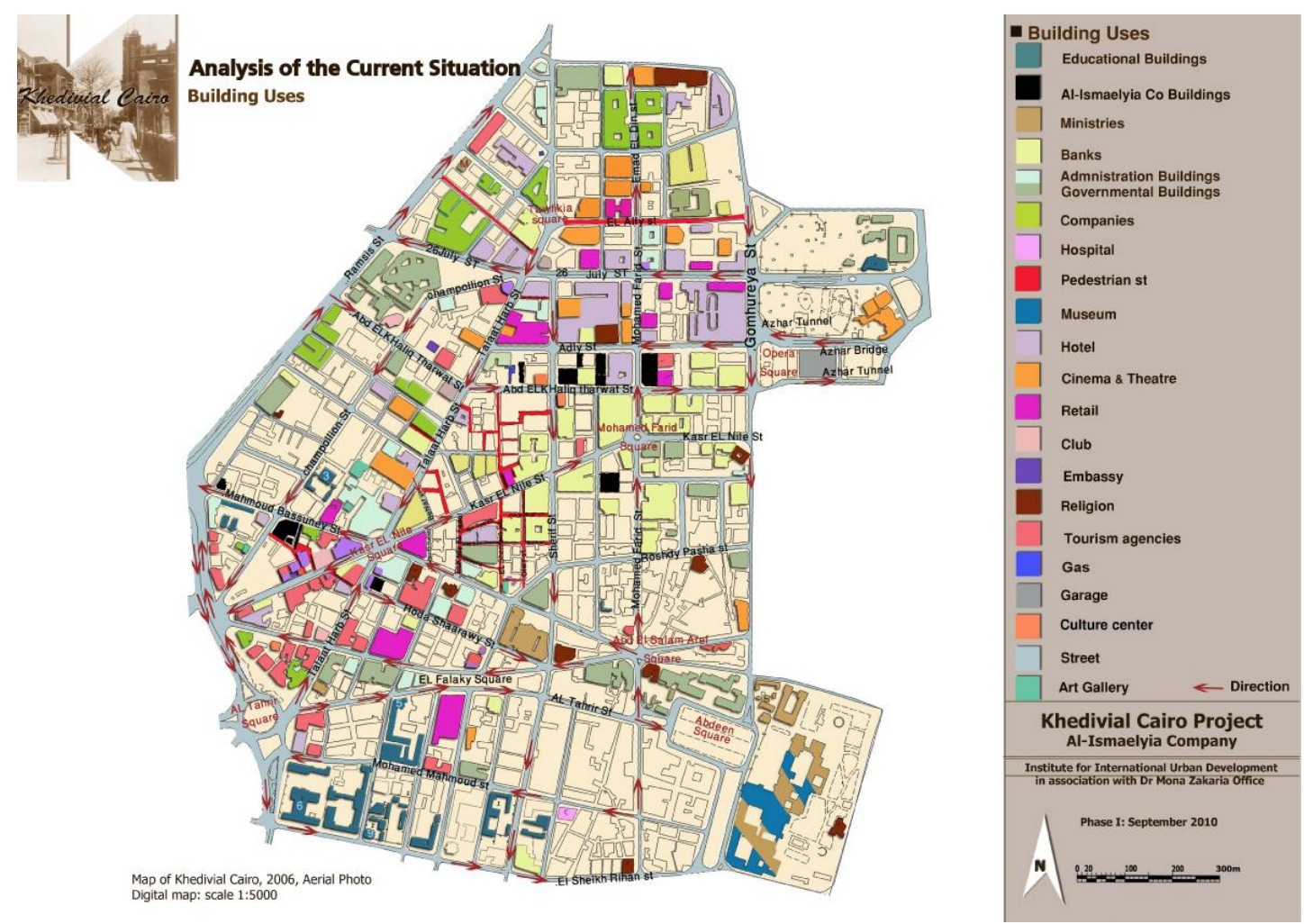

Map of Khedivial cairo, 2006, Aerial photo

Source : Al-ismaelyia company

6.2.3 Effect of sustainable development on approaches of investment employment in the area

There is a close relation betweenKhedivial Cairo and development of tourism and economy by developing skills and professions. Thus, value of this area lies in clarifying its role in development by achieving the following ${ }^{20}$ :

- Creating job opportunities to raise the levels of living and develop the production centers in accordance with the nature of heritage scope.

- Following the uses of lands to exploit and develop it in a way which benefits the heritage scope and increases its efficiency and attraction.
- Collaboration between local associations and private sector in development aiming to spread the awareness of value of this area, and making it connecting point between citizens and competent authorities.

- Determining the touristic sufficiency and the extent of touristsattraction and developing it through touristic projects attract tourists and achieve the required revenue to raise the level of income. 
6.2.4 Administrative guidelines to be taken when executing projects of reemployment as follows

- preparation and restoration of buildings to recognize the projects of conservation of heritage scopes by the best ways.

- Persuading the stakeholders and landlords of the benefit and role of the project to support the confidence to the authorities based on the project.

- Determining weaknesses and strengths of the project to be developed.

- Training the working cadres in the field of work to widen the scope of work.

- Inserting the guide projects to intensively supervise by specialized persons through stages of preparation, design and execution.

- Scope is divided into smaller areas or group of buildings to be dealt with by a particular guide style. It can be divided according to specializations; for example, support processes, qualifying again, maintenance works, finishes, paintings of scope buildings, providing maintenance planregularly every five years, and putting responsibility upon one of the property owners. In case non compliance, conservation processes of heritage area will be finished by administration of urban heritage in the governorate.

- Determining the competent authority of urban heritage administration including following maintenance and conservation works by experts and specialized personssupervised by the national organization of urban harmony.

\section{3 administration of sustainable investment of the Khedivial Cairo area}

There are many organizational, legal and administrative factors participate in shaping the administrative system, it can be clarified as follows ${ }^{21}$ :

- Formation of a specialized committee including all concerned specializations and will be responsible for the area, no decision will be made after committee's approval. It participates in activating policies of sustainable development. This can be dome in cooperation with competent authorities including facilities, localities and so on.

- Urging the effective participation of the private and public sector by providing special places of new investments and increasing awareness and education programs to spread the spirit of belonging to the area.

- Legal and legislative factors, it represents the regulations made to organize how to deal with this area which suits the nature and importance.

- Formation of media policies to attract investors, sector and banks by:

- Indirect encouragement by government to help investors facilitate the custom and tax reductions.
- Activating the role of popular participation by different media.

- Organizing competitions between parts of the areamade by competent committee in the area by dividing it into parts, and providing incentives and rewards as facilities by government, and cleaning processes, compliance with the building requirements, periodic maintenance, regulations and special stipulations.

- Popular participation: it is made by activating their role by upgrading the area through providing ways of welfare and making them feelgenerally concerned with the area and conservation of it.

- Regular meetings between the formed committee and individuals to discuss the solution of development problems and making local councils for the society to participate in solving the problems of society individuals.

6.4 Facilities of investors in the area of Khedivial Cairo Investors try to invest their money by making projects in the area which suit the economic and historical value and which does not cause the loss of these values, in addition to making use of development energy in the area,the heritage resource is the most important. On the other hand, cooperation with the local government in financing and executing the service projects which cause public benefit.

The following must be provided to realize the suitable climate for the investors in this area:

- Raising the efficiency of facilities and public services.

- The ability to reuse the valuable buildings in commercial, touristic and cultural projects by commitment to the international charters to deal, which is proposed by the competent administrative authority in the area.

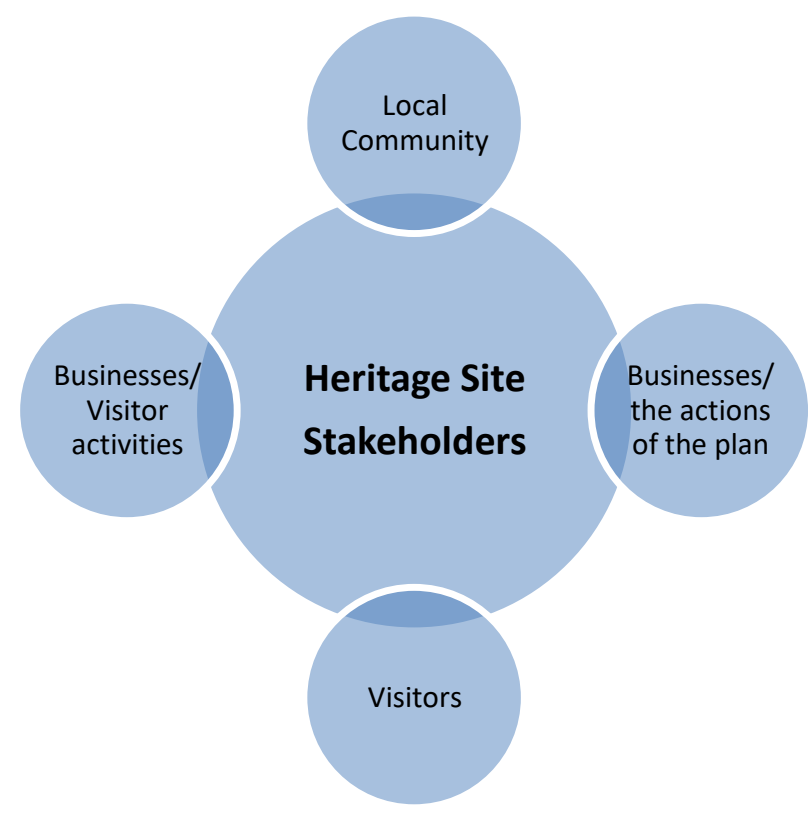


- System of temporary custom and tax relief for investments which increases the element of investment competition.

6.5 plan of administration of visitors and stakeholders

There may be a contradiction between the shared interests of stakeholders concerned with different environmental, social and economic fields. Hence, plan of visitors administration tries to balance between the contradictory situations, and to reach a compromise to satisfy all parties. This can be overcome by putting methodology through which stakeholders can discuss their issues, determine targets and solutions at the beginning of plan.

Providing plan of visitors administration resulted the following:

- Making tourism in the desirable direction by realizing goals.

- $\quad$ Realizing satisfaction of visitors and improving control over visitors' behavior.

- Conservation of heritage and heritage scopes which contain elements and ownerships.

- $\quad$ Realizing investments and directions to market the heritage location.

6.6 Results of economic evaluation of sustainable investment

Economic evaluation of sustainable investment of urban heritage is considered a relatively new field. International bank is considered one of the leading offices in this regard, as there is a big increase reflects a strong request of bank loans and investment services by customers especially in the field of conservation ${ }^{22}$. Through projects of heritage conservation the bank aims at reinforcing the cultural identity of a country or and a particular geographical area to raise the ability of heritage in processes of economic and social development of the society, and reinforcing the ability in tourism. Financing is considered the most important main basics of sustainable development in developing countries, the particular material resources are limited, this requires true employment to decrease the loss as possible as one can. Value of international cooperation appears in providing financing necessary to execute the investment projects to support the sustainable investment by the effective participation between the government authorities and private sector as a result of the great responsibility upon the government and inability to provide balances of maintenance and protection processes.

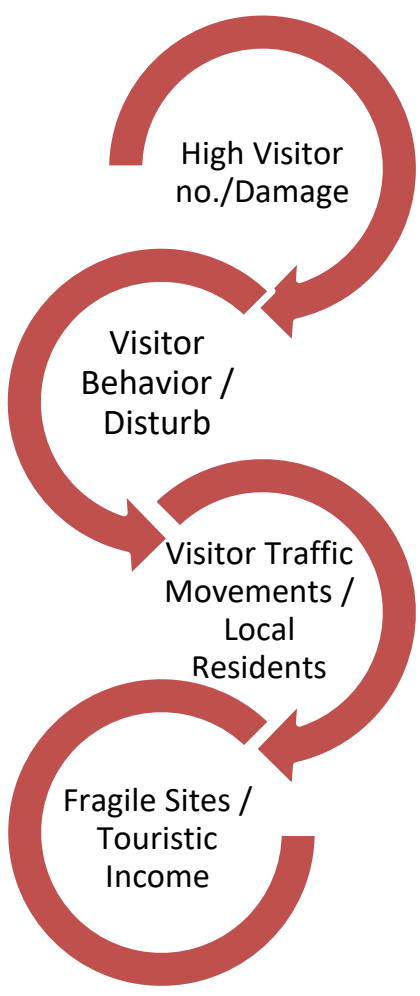

\section{RECOMMENDATIONS OF SUCCESS OF INVESTMENT AND FINANCINGPROGRAMS}

Thus, we recognize the most important recommendations and activating successful investment programs in the heritage scopes, and realizing financing necessary to protect the urban heritage as follow ${ }^{23}$ :

- Establishing government investment companies particularly its role is investment in heritage scopes according to laws and rules for conservation of heritage scope nature. It realizes profit, development and compatibility between them, organizing control departments by competent authorities to assure performance of all jobs and realizing the desirable targets.

- Forming local organization, its special resource will be the revenues including contributions and activities. These revenues are allocated to conservation and development of heritage scopes to activate the self effortsand realize the popular participation in financing projects of urban heritage conservation and development by organizations of civil society.

- Attracting investments to heritage areas by touristic employment ofthe architectural and urban constituents of the area, and exploiting human and material resources artistically and administratively. Trying to revive heritage professions and finding what is suitable in the area.

- Supporting international institutions to allocate the programs of supporting finance to upgrade heritage scopes.

- Rapidly putting clear and shared view of urban employment policies according to complement 
programs including all competent authorities, and depends on the economic development and social and cultural activity.

- Formal and societal authorities hold marketing tours to make the society aware of the areas of urban heritage and its value, a part of the general balance is allocated by the government to market and finance these projects.

- Distribution of resources according to an economic method activates the role of investment by redistribution of production sectors and taking care of the social aspect as housing area, organizing determinants of rates and wages help encourage investment and landlords by processes of periodic maintenance of buildings.

- Invention of smart incentives and tax facilities by the government aiming at attracting investors, stakeholders and investors to heritage properties, to encourage them participate in sustainable development and urban conservation and reemploying it.

\section{REFERENCES}

[1] Rashed Ahmed Yahya. Other, investment as the cornerstone for the preservation of heritage areas. Case Study of Al MoezLedeen Allah Fatimi Street, Research and Heritage 3 Urban Heritage Studies, 2013.

[2] GSIA: Global Sustainable Investment Alliance،" Global Sustainable Investment"، January ‘2013.

[3] Al-Humaidi, Walid bin Kassab,-Suwaidan, Mansour, Symposium on the partnership between the municipal and private sectors, Municipality of Al-Deraiya Governorate - Supreme Commission for Tourism, 2008

[4] Donia,Shatha, Sustainable Investment In Architectural Heritage Building, Journal of Engineering, Uruk, 2017.

[5] Guidelines (Principles and Criteria for Civilization Coordination of Buildings and Heritage Areas), National Authority for Civilization Coordination - First Edition, 2010

[6] Youssef, Mohamed Mahmoud Abdullah, Urban Heritage Investment Programs and Financing Methods Based on Arab and International Experiences, Urbanization Research Bulletin, Faculty of Regional and Urban Planning, Cairo University, 2014.

[7] Urban Heritage: Urban Identity and National History, SCTA, 2014.

[8] Manshawy, Ahmed Alshahat, partnership in conservation projects, PhD, Cairo University, 2013.

[9] Sulaiman, Mohamed, Awwad; Ahmed, Methodology of Dealing with Areas of Historical Value (Cairo Case Study of Khedive), Research Paper, Banha University, Egypt, 2011.

[10] De ascaniis, Silvia, Gravari-babas, maria, cantoni, Lorenzo, Tourism management at unesco world heritage sites, paris, france, 2018,

[11] Previous reference (n.7).

[12] Halafawy, Omar Mustafa Kamal, "Re-employment as one of the guiding principles of the process of urban conservation in developing countries" Fourth International Scientific Conference, Faculty of Engineering, Al-Azhar University, 1995

[13] Sultan, Mohamed Sayed, Urban Heritage Finance Issues: Strategic Framework for Promoting Heritage Conservation and Protection, Research and Heritage of 3 Urban Heritage Studies, Third National Heritage Heritage Forum, 2013.

[14] Law No. 119 of 2008 and its Executive Regulations, 2011.

[15] Sulaiman, Mohamed, Awwad; Ahmed, Methodology of Dealing with Areas of Historical Value (Cairo Case Study of Khedive), Research Paper, Banha University, Egypt, 2011.

[16] Hawass, SuhairZaki, Cairo Khedive Observation and documentation of Amara and Amran Cairo in downtown Cairo, Egypt, 2002.
[17] Previous reference (no.9).

[18] Blue \& green tomorrow ,"sustainable investment " , 4th edition, 2014

[19] Zakaria, mona, Revitallization strategies for areas in Khedivial cairo,Assessment report, 2011.

[20] Standards of the civilizational coordination of the buildings and heritage areas with the distinct value approved by the Supreme Council for Planning and Urban Development, in accordance with Law No. 119 of 2008.

[21] Makkawi, HalaSaad, Policies of Dealing with Areas of Historical Value in the Framework of Sustainable Development, published research, Faculty of Regional and Urban Planning, Cairo University, 2004.

[22] Manshawy, Ahmed El-Shahat, Private Sector Partnership in Urban Conservation Projects, Research and Heritage of 3 Urban Heritage Studies, Third National Heritage Heritage Forum, 2013.

[23] Previous reference (no.6).

[24] Urbanharmony.org 